\title{
Why do banks promise to pay par on demand?
}

\author{
Gerald P. Dwyer Jr. ${ }^{\text {a,b,* }}$, Margarita Samartín ${ }^{\text {b }}$ \\ a Research Department, Federal Reserve Bank of Atlanta, 1000 Peachtree St. N E., \\ Atlanta, GA 30309, United States \\ b Universidad Carlos III de Madrid, Departamento de Economía de la Empresa, \\ Calle Madrid, 126, 28903 Getafe, Madrid, Spain
}

\begin{abstract}
We survey the theories on why banks promise to pay par on demand and examine evidence on the conditions under which banks have promised to pay the par value of deposits and banknotes on demand when holding only fractional reserves The theoretical literature is divided into four strands: liquidity provision; asymmetric information; legal restrictions; and a medium of exchange We assume that it is not zero cost to make a promise to redeem a liability at par value on demand If so, then the conditions in the theories that result in par redemption are possible explanations why banks promise to pay par on demand If the explanation based on customers' demand for liquidity is correct, payment of deposits at par will be promised when banks hold assets that are illiquid in the short run If the asymmetric-information explanation based on the difficulty of valuing assets is correct, the marketability of banks' assets determines whether banks promise to pay par If the legal restrictions explanation of par redemption is correct, banks will not promise to pay par if they are not required to do so If the transaction explanation is correct, banks will promise to pay par if the deposits are used in transactions We examine the history of banking in several countries in different eras: fourth century Athens, medieval Italy, Tokugawa Japan, and free banking and money market mutual funds in the United States Each of the theories explains some of the observed banking arrangements and none explains all of them
\end{abstract}

Keywords: Banking panics; Suspension of payments; Banking history; Money market funds

\footnotetext{
* Corresponding author Tel +1 404498 7095; fax +1 4044988810

E-mail addresses: gdwyer@dwyerecon com, gerald p dwyer@atl frb org (G P Dwyer Jr), samartin@emp uc3mes (M Samartın)
} 


\section{Introduction}

Banks promise to pay the par value of certain liabilities on demand with fractional reserves of the assets promised. It is trivially obvious that, due to gamblers' ruin, no bank holding fractional reserves can expect to honor this promise forever. No bank customer can expect it to be honored always either. In addition, the consequences - banking panics - are not trivial. In the United States, banking panics happened during the free banking and National Banking periods and at the start of the Great Depression. These are far from unique historically, and banking crises in emerging countries are more recent examples of related events. ${ }^{1}$

Given that these things are so, why do banks promise what they cannot deliver in the first place?

It is possible that banks promise to pay par on demand because depositors want this contractual agreement. There are at least four possible reasons for this desire. Depositors may demand a constant par value because this makes their deposit balances more predictable under typical circumstances, thereby increasing the liquidity of deposits compared to assets that have a longer maturity. At many times and places, banks have held largely nonmarketable assets; hence, customers cannot easily assess the assets' market values. Under these circumstances, deposit values that vary with the value of banks' assets may not be a feasible market equilibrium and redemption on demand can keep the bank from dissipating the depositors' wealth by exploiting superior information. Depositors may want a constant par value because it is more convenient when using deposits in transactions, a point that may be related to the predictability of balances in the liquidity explanation. Alternatively, banks may make this promise simply because they are required to do so by law and such promises would not occur without that requirement.

In this paper, we survey theories about banks' promise to pay par on demand to determine the empirical predictions about when financial intermediaries will promise to pay par on demand. We assume that it is not costless to make a promise to redeem a liability at par value on demand. While the theories are highly stylized, there are conditions leading to par redemption in the theories and we interpret those conditions as possible explanations why banks promise to pay par on demand.

We show that these theories are informative for understanding banking arrangements, making predictions about when banks will promise to pay par on demand and when they will not make such promises.

There are two alternative interpretations of the theories, which we characterize as the strong and weak versions of the theories. In the strong interpretation of the theories, the theories make a prediction, namely that promises to pay par on demand will occur only under conditions consistent with the theory. This is similar to some theories in economics and finance, such as the law of demand which predicts that a higher price will decrease quantity demanded. Alternatively, the theories can be interpreted as making weak predictions, sometimes explaining why banks promise to pay par on demand but one theory need not explain all of the observations. It could be argued that a non-redundant theory will explain something not explicable by the other theories.

After this survey of the theoretical literature, we examine the history of banking in several countries in different eras: fourth century Athens; medieval Italy; Japan during its period of "seclu-

\footnotetext{
${ }^{1}$ For United States history, Dwyer (1996) summarizes some banking panics before the Civil War in the United States, Sprague (1910) summarizes banking panics in the National Banking period, and Friedman and Schwartz (1963) analyze the banking panics at the start of the Great Depression Over 8000 banks failed in the U S from 1929 to 1933 (Friedman and Schwartz, 1963) Banking problems have not ended with the establishment of central banks Lindgren and Saal (1996) indicate that 73 percent of the IMF's member countries suffered banking crises between 1980 and 1996
} 
sion"; and the United States. We picked these cases instead of others to mitigate the sequential dependence of the episodes examined. Western European banking development partly reflects experience in Italy, to the point that Lombard Street in London has a name based on the Lombardy bankers who set up business there. We examine banking in Japan because Japan was more or less secluded from the rest of the world for over two centuries and it is the country outside Western Europe with the largest English literature on its banking history. We examine the United States because free banking on the U.S. frontier has some novel aspects, as do money market mutual funds. Truly independent observations would require examining banking on different planets before interplanetary travel - an impossibility today. While not independent, these historical episodes are not completely dependent and the empirical evidence is consistent with some independence.

The bottom line of our empirical analysis can be summarized simply. None of the currently existing theories explains all of these episodes from banking history. All of the theories explain one or more episodes.

\section{Theoretical explanations for the use of demand deposits}

A bank that takes in deposits and invests the proceeds in long-term loans exposes itself to many risks: the risk that depositors withdraw their funds, the risk that market deposit interest rates rise, and the risk that borrowers default with collateral worth less than the deposit funding the loan. These risks are correlated with each other and are driven by common macroeconomic factors (Hellwig, 1998).

It is not immediately obvious why banks promise to pay the par value of deposits on demand when they hold risky assets and only fractional reserves of the asset that they promise to deliver on demand.

Theoretical research on banking provides four general explanations for making this promise: provision of liquidity, asymmetric information, legal restrictions and deposits' use as a medium of exchange. In this section, we summarize the basic theoretical analyses behind these explanations of par redemption on demand and their empirical implications. ${ }^{2}$

\subsection{Liquidity provision}

One possible explanation for the use of demand deposit contracts is associated with liquidity insurance provided by financial intermediaries. Diamond and Dybvig (1983) introduce a demand for liquidity by the public which supports a transformation of assets' returns provided by banks. Diamond and Dybvig demonstrate that demand deposit contracts which transform illiquid assets into more liquid liabilities can explain both banks' existence and the existence of bank runs.

In the simplest formulation of this class of models, there is a continuum of ex ante identical agents who are risk averse and uncertain about the timing of their desire to consume. These individuals are endowed with one unit of the good in an initial period $T=0$ and no additional endowment in subsequent periods. ${ }^{3}$ The agents have a privately observed risk at $T=1$, with a nonzero probability of being early consumers who derive utility only from consumption in period

\footnotetext{
${ }^{2}$ In Dwyer and Samartín (2006), we present the material in this section with mathematical details

3 The model presented is simpler than Diamond and Dybvig's but has the same implications in terms of promised payment and runs
} 
one and a nonzero probability of being late consumers who derive utility only from consumption in period two. Consumers can privately store the good with no appreciation or depreciation. There also is an investment technology available to consumers in which a unit investment at $T=0$ yields one unit at $T=1$ or more than one unit at $T=2$. In autarky, early consumers liquidate their investment at $T=1$ and consume one unit; late consumers maintain the investment in the technology and receive the higher return at $T=2$. There is no aggregate uncertainty: the fractions of agents who are early and late consumers are the same as the probabilities of any individual agent being an early or late consumer. ${ }^{4}$

Diamond and Dybvig show how a financial intermediary can improve consumers' ex ante welfare by offering them a demand deposit contract. This deposit contract can support the fullinformation risk-sharing equilibrium. The Pareto optimal solution is obtained by maximizing the ex ante expected utility of agents subject to the resource constraints implied by the investment opportunity set. If the representative agent's relative risk aversion is greater than one, the optimal solution in effect is an insurance contract that provides early consumers with more consumption than in autarky, late consumers with more consumption than early consumers but with less consumption than in autarky. This optimal contract insures depositors against being early consumers in the sense that consumption by early consumers is greater than in autarky and consumption by late consumers is less than it would be in autarky.

A deposit contract can achieve this optimal allocation. The demand deposit contract works as follows. For each unit deposited in the intermediary at $T=0$, the deposit contract provides the option of withdrawing either the Pareto optimal amount at $T=1$ or an amount contingent on the fraction of early consumers at $T=2$. If only early consumers withdraw at $T=1$, the demand deposit contract replicates the optimal allocation.

Implementing this allocation, however, subjects the intermediary to a possible coordination problem because a consumer's preference for early or late consumption is private information and the intermediary cannot guarantee that only early consumers withdraw at $T=1$. In fact, late consumers' withdrawals are strategic and depend on what other agents do. If some late consumers withdraw at $T=1$, then the fraction of early withdrawals is greater than the fraction of early consumers and the payoff to late withdrawers is less than the Pareto optimal amount. If enough late consumers withdraw at $T=1$, then the payoff to late withdrawers is less than the payoff to early withdrawers and everyone withdraws at $T=1$, which can be interpreted as a bank run.

In this model, there are two Pareto-ordered Nash equilibria: a Pareto dominant equilibrium that achieves socially optimal risk sharing in which only early consumers withdraw at $T=1$; and a second equilibrium in which all agents withdraw at $T=1$, which is the bank run equilibrium. The model can be used to show that there are several measures to prevent the occurrence of the bank run equilibrium. ${ }^{5}$ The equilibrium arguments implicitly assume a sequential service constraint in which depositors are paid on a first-come, first-served basis, an assumption that motivates the papers by Wallace $(1988,1990)$.

\footnotetext{
4 This is a detail in autarky but an important part of the model with financial intermediaries

5 If there is no aggregate uncertainty about the proportion of early consumers, the Pareto optimal equilibrium could be implemented by a policy of suspending convertibility once withdrawals equal the fraction of early consumers This policy removes the incentive for late consumers to withdraw early; with this policy, late consumers always obtain a higher payoff if they wait until the second period than if they withdraw in the first period If there is aggregate uncertainty, though, this measure is not effective for some realizations of the fraction of early consumers
} 
There have been several later developments of this analysis. Jacklin (1987) shows that the optimal deposit contract also can be achieved by trading equity. He also shows that demand deposits and equity are equivalent risk sharing instruments if demand deposits can be traded in a central market. ${ }^{6}$ Jacklin then argues that financial intermediaries exist because trading restrictions limit consumers to demand deposit contracts of the Diamond and Dybvig type, a conclusion also reached by Haubrich and King (1990). Such trading restrictions can be motivated by agents' isolation from each other. ${ }^{7}$

Agents demand liquid assets because they are impatient to spend and do not have access to asset markets in which they can sell the assets at market prices. Instead they go to the bank to withdraw funds and the bank sequentially serves depositors. Wallace $(1988,1990)$ explicitly incorporates a sequential service constraint in the Diamond and Dybvig model. An important implication of these models is the necessity of some form of isolation of agents to motivate the illiquid banking arrangements. Otherwise, individuals generally would want to participate in an asset market which is superior to illiquid banking.

Further work in this area has examined the role of demand deposits when there is a securities market in which agents can meet and trade (Diamond, 1997; Von Thadden, 1998). Diamond (1997) examines the roles of banks and markets when there is a financial market but with limited participation in the financial market. Such a market has an impact on bank activities but banks remain important. The paper focuses on the interactions between the bank provision of liquidity and the participation in the market. As more agents participate in the market, banks are less able to provide additional liquidity. The paper delivers the Diamond and Dybvig result when there is no participation and the Jacklin result when there is full participation.

In summary, this strand of the literature argues that banks offer to pay par on demand in order to provide liquidity insurance to individuals who are uncertain about their future time preferences when investment opportunities are inconsistent with preferred consumption paths of consumers. While these theories can be interpreted as implying that deposits will pay interest, it is not necessary that they do so because nonpecuniary services can be a substitute for explicit interest payments. Depositors demand liquid assets because they are impatient to spend and they do not have access to financial markets in which they can sell the asset at its market price. $^{8}$

\footnotetext{
${ }^{6}$ Other papers in the literature have analyzed the relative degrees of risk sharing provided by banks and equity contracts (Jacklin and Bhattacharya, 1988; Hellwig, 1994; Alonso, 1996; Samartín, 2001)

${ }^{7}$ Recent criticisms of the Diamond and Dybvig model by Green and Lin $(2000,2003)$ analyze why banking evolved with uninsured demand deposits They examine the significance of the simple deposit contract and find that it is critical: confining agents to this type of contract is, in fact, the driving force behind the bank run equilibrium of the model Green and Lin show that when agents in the Diamond and Dybvig model are allowed to use a broad class of banking contracts, the bank run equilibrium disappears even in the presence of a sequential service constraint Their results suggest that economists need to attempt to understand the economic and legal environment that produces the simple deposit contract In a later paper, Peck and Shell (2003) show that even when banks can write more sophisticated contracts, bank runs are possible Goldstein and Pauzner (2005) address some of the more fundamental problems with the multiplicity of equilibria in Diamond and Dybvig's model

${ }^{8}$ There have been several attempts to extend the Diamond and Dybvig framework to an overlapping generation context and to analyze liquidity provision by banks, without the necessity of imposing trading restrictions as in the singlegeneration models Examples of such work are Qi (1994), Bhattacharya and Jorge Padilla (1996), Bhattacharya et al (1998), Fulghieri and Rovelli (1998) and Qian et al (2004)
} 


\subsection{Asymmetric information}

A second explanation for the use of demand deposit contracts with par payment is linked to asymmetric information about loans: banks make loans with values that are costly for others to verify, bank managers' behavior is costly to monitor, and some depositors acquire information about the realization of the random return.

We continue to assume there is a continuum of ex ante identical agents who are risk averse and uncertain about their preferences concerning consumption. As in Diamond and Dybvig, they are subject to a privately observed risk of being early consumers and are endowed with one unit of the good in an initial period $T=0 .{ }^{9}$

There are two assets: a short-term asset and a long-term asset. The short-term asset generates a gross return of one unit at $T=1$ for each unit invested at $T=0$. The long-term asset has a random return at $T=2$, which can be either a high value or a low value with nonzero probabilities. For simplicity it is assumed that this long-term asset can be liquidated at $T=1$ only at sufficient loss that it never pays to do so. Banks possess private information about their loan portfolio which can lead to inefficient allocations with liquidation of loans.

The bank offers depositors a demand deposit contract in exchange for their endowments. This deposit contract provides the option of withdrawing at $T=1$ or at $T=2$. At $T=2$, depositors can withdraw the Pareto optimal consumption. At $T=2$, the depositors receive a random return which depends on the fraction of agents who withdraw at $T=1$ and the realized return from the investment in the long-term asset. One way to think about this random return is that the bank promises an amount at $T=2$ which it can pay if the realized return equals the high return. If the low return is realized, the bank is considered insolvent and depositors get a fraction of their promised payments on liquidation of the bank.

At $T=1$, a fraction of late consumers receive correct information about the random return. ${ }^{10}$ Given this information, informed late consumers select their optimal strategy. If they receive negative information and the payment at $T=1$ is greater than the liquidating return at $T=2$ from the bank, they prefer the promised first period payment to the second period payment and all informed late consumers withdraw in the first period. In this bank run equilibrium, the bank exhausts the liquid asset among withdrawals by depositors, which includes both early consumers and informed late consumers. After withdrawals by the fraction of customers equal to the fraction of early consumers, payments are suspended and withdrawals are allowed in the second period only. As a result, some early consumers almost surely are not able to withdraw at $T=1$. $^{11}$

Jacklin (1993) extends the basic framework based on Diamond and Dybvig described above and introduces aggregate uncertainty regarding the proportion of early consumers in the population. If there is both aggregate uncertainty and risky bank assets with depositors and banks

\footnotetext{
9 The model presented is simpler than Jacklin and Bhattacharya's but has the same implications in terms of the origins of bank runs and its policy implications Other papers such as Chari and Jagannathan (1988) and Allen and Gale (1998) also have versions of this basic setup

10 This assumption is motivated by the observation that, if information were costly, late consumers would be more likely to purchase information Also, if depositors were of different sizes, larger depositors would be more likely to acquire information These unmodeled aspects of the problem are captured by assuming that a fraction of late consumers is informed

11 Given the complete irreversibility assumption of the long-term investment, pure panic runs of the Diamond and Dybvig type are excluded because there is no coordination problem among late consumers Independent of what other agents do, informed consumers always obtain a higher payoff in the good state if they wait until the second period to withdraw because the bank pays a higher payment in the second period than in the first in the good state
} 
asymmetrically informed about the risky asset quality, then demand deposits and equity contracts are not equivalent risk sharing instruments. Other papers (Gorton and Pennacchi, 1990; Jacklin, 1993) have emphasized that liquid deposits protect uninformed depositors from losses they would otherwise suffer when trading securities such as equity with better informed individuals.

In this class of models, banking panics are not a manifestation of an inherent problem with banks or banking contracts; they are a rational response by depositors to a bad state of the world. This is consistent with empirical evidence, which indicates that banking panics are explicable responses to bad states of the world (Rolnick and Weber, 1984; Gorton, 1988; Economopoulos, 1990; Dwyer and Hasan, 2007).

A number of papers have focused on the incentive properties of demand deposits. In these papers, liquid deposits keep the bank's portfolio choice in line with depositors' preferences. The framework is similar to the one described above, but it includes the possibility that banks take actions that benefit the banks' owners and make depositors worse off. In these papers, the threat of a bank run by informed depositors after receiving negative information discourages banks' owners from investing in excessively risky projects or committing fraud. In this way, demand deposits discipline bank managers and reduce moral hazard problems. The deposit contract serves this role due to the combination of two inherent characteristics: the on demand clause and the sequential service constraint. The demandable nature of the contract motivates some depositors to monitor the bank, while the sequential service constraint discourages free riding by depositors on others' monitoring (see Calomiris and Kahn, 1991; Flannery, 1994; Jean-Baptiste, 1999; Gorton and Huang, 2002, 2003). ${ }^{12}$

This strand of the literature argues that banks' promise to pay the par value of deposits is due to asymmetric information about banks' assets. The demand deposit contract can keep the bank from dissipating depositors' wealth by exploiting information available to the banker but not to depositors. The demand deposit contract also protects uninformed depositors who would be disadvantaged relative to better informed individuals if banks offered equity contracts. The deposit is payable on demand and this contract imposes costs on the bank if it deviates from the equilibrium strategy.

\subsection{Legal restrictions}

A third explanation of why banks promise to pay par on demand is provided by the legal restrictions theory, which attempts to explain the coexistence of alternative assets some of which have significantly higher returns than others and all of which have little or no nominal risk (Wallace, 1983, references therein and Bryant, 1989). As Wallace (1983) points out, an example of these paradoxical patterns of returns among assets is the coexistence of U.S. currency, bank deposits and default-free interest bearing securities such as U.S. savings bonds and Treasury bills. If currency, deposits and Treasury securities are perfect substitutes, no agent would hold non-interest bearing currency or non-interest bearing deposits instead of Treasury bills. This coexistence can be explained by legal restrictions on Treasury bills which prevent them from playing the same role in transactions as do currency and deposits. Bryant and Wallace (1984) argue that such restrictions make it possible for the government to levy taxes more efficiently. If all three assets were allowed to be used in transactions without any legal restrictions, the prediction

${ }^{12}$ Qi (1998) and Diamond and Rajan (2001a, 2001b, 2005, 2006)also study the disciplinary effects of liquid deposits in models that abstract from asymmetric information 
is that either nominal interest rates would go to zero or government currency and bank deposits would trade at discounts from redemption value, in this way yielding interest as time approaches maturity.

In summary, Wallace argues that banks promise to pay par on demand because of legal restrictions which also explains why other securities do not play the same role as demand deposits. There is a question of who gains from such a legal restriction. The argument could be made that the legal restriction merely formalizes a typical market contract. The counter-argument would be that the beneficiaries are the banks who have less competition than without legal restrictions on securities being used as a transactions medium. The government also can gain by separating the market for securities that pay interest and transactions media that pay no interest. If the legal restriction explanation of par redemption is correct, banks will not promise to pay par unless they are required to do so.

\subsection{Bank liabilities as a medium of exchange}

Other models have been built based on the observation that bank liabilities function as a medium of exchange and payment (Williamson, 1992; Freeman, 1996a, 1996b; Green, 1997; McAndrews and Roberds, 1999). In general, these papers consider a framework in which agents are either spatially separated, so they cannot contract and trade with everyone else at the same time, or there are other frictions such as problems of contract enforcement or adverse selection. The papers can be interpreted as having implications for the question of whether banks pay par value, although the connection is not immediate.

Freeman's (1996a) and Green's (1997) papers are similar, with both modeling the structure of trade and the stochastic component of agents meeting to trade. Repayment of debt at par value is optimal in these papers and the analyses are similar in various respects, with Green clarifying some issues in Freeman's analysis.

In Green's (1997) model, the structure of trade among agents requires debt outstanding within the period. Efficiency requires that the market value of this debt be par value, because otherwise agents will be subject to uncertainty concerning whether they will be faced with a transaction in which they receive less than par value. Depending on parameters in the model, an equilibrium with agents acting only to buy and sell their own goods may not be efficient. A central bank and possibly a clearinghouse can provide a guarantee that the debt within the period will clear at par value.

In models by McAndrews and Roberds (1999) and Kahn and Roberds (2004), trading away from par value also is inconsistent with optimality. Although trading at par value is assumed in these models, it may be possible to motivate par redemption by issues of private information and resultant adverse selection.

Private agents issue debt claims to facilitate paying for purchases. One issue that arises is the pricing of these debt claims - if the number of agents arriving to trade is not consistent with this debt trading at par, the liabilities trade away from par. These papers point out that an important characteristic of a medium of exchange may be that it entails little or no risk, i.e. its value is independent of the state of the world.

From a narrow point of view, these papers are insufficiently developed to show that financial intermediaries will promise to pay par value. From another point of view, they point toward conditions that are likely to be necessary to have this implication.

For our purposes, without any implication of the conclusion directly following from the existing literature, this literature does suggest that the use of bank liabilities as a medium of exchange is 
Table 1

Summary of implications of theories

\begin{tabular}{ll}
\hline Theory & Primary antecedent condition for par redemption \\
\hline All & $\begin{array}{l}\text { Banks promise to pay par on demand with only fractional reserves of } \\
\text { the promised asset } \\
\text { Bank assets are exchangeable into the liability over time, at significant } \\
\text { Liquidity provision }\end{array}$ \\
Asymmetric information & $\begin{array}{l}\text { Banks are better informed about assets than depositors with no truth } \\
\text { revealing equilibrium }\end{array}$ \\
Legal restriction & $\begin{array}{l}\text { An enforced law requires bank to pay par on demand } \\
\text { Bank liabilities are used as a medium of exchange }\end{array}$ \\
\hline
\end{tabular}

This table summarizes the implications of the theories The condition "with no truth revealing equilibrium" is an important part of the asymmetric information theory but it is untestable, at least in the context of our analysis, so we do not consider this condition in our analyses of actual banking

an important characteristic. In our analyses of banking systems, we will take note of the ones in which bank liabilities are used as a medium of exchange.

\section{Evidence}

This analysis implies that there are certain crucial questions to be asked in our summary of banking histories. Table 1 summarizes the basic analytical results in the theoretical analyses and suggests the questions to be asked about banking arrangements. First, did one or more institutions accept deposits and promise to pay their par value on demand and, if so, did they hold fractional reserves of the underlying asset promised? If so, was there a legal requirement that the banks promise to pay par value? What assets did the banks hold? Were banks' assets illiquid: exchangeable into the promised asset only over time or at a significant cost? Did a large fraction or all of the assets held by the banks have an idiosyncratic component under circumstances consistent with asymmetric information? Were the liabilities of the banks used as a medium of exchange?

\subsection{Athens, fourth century B.C.}

Despite the difficulty of determining events over two millennia ago, certain aspects of banks' operations in ancient Athens are quite clear and quite pertinent for evaluating banking theories. ${ }^{13}$ Much is generally agreed upon by scholars, even though there is uncertainty and controversy. ${ }^{14}$ We indicate where those disagreements affect our conclusions. ${ }^{15}$

\footnotetext{
13 The sources of much of the surviving evidence provides some indication of the reliability and possible biases in the information available Millett's book-length analysis is based on the evidence from the Attic Orators's speeches: "published versions of their commissioned speeches" (Millett, 1991, p 2); Cohen's book-length analysis is based on the evidence from court cases (Cohen, 1992, p 27)

14 The discussion in Andreau (1999) and Temin (2004) indicates that, other than the type of loans made, much of the analysis carries over to Ancient Rome

15 The discussion in this section of the paper largely relies on Thompson (1979, 1982, 1988), Millett (1991) and Cohen (1992) A contentious issue in the literature is whether loans were for "productive" or "unproductive" purposes If mapped into commercial and consumption loans, this discussion makes some sense even though the reason for the discussion whether Athens' economy was "primitive" - is irrelevant to our analysis More generally, the issue is whether loans were impersonal transactions or loans generally were made to people with whom the banker had some personal relationship,
} 
Banks were unincorporated enterprises which were money changers before becoming fullfledged banks. Bankers operated their businesses at tables in the marketplace. At these tables, bankers provided currency exchange, accepted deposits of both money and other assets and made loans. Banks generally were sole proprietorships, with some possibly being partnerships. There is no evidence of regulations that applied to banks' operations other than the general set of laws applied to commercial activities. ${ }^{16}$

A banker was liable for deposits up to the value of all of the banker's assets, and the banker was liable for the initial value of all assets deposited. Deposits in banks could be transferred to others, but there were no banknotes or checks, instruments for which the underlying legal foundation had not been laid.

Overall, the evidence is consistent with fractional reserve banking. Absent enough information to create balance sheets, it is not certain whether banks generally had fractional reserves, but there is no evidence that bankers made loans only with their own capital and there is no evidence that banks holding fractional reserves were considered to be fraudulent or otherwise illegal.

Transfers could be effected only by physically going to the bank. Some comments about foreign traders suggest that the depositor did not always have to be present to make a transfer, but the recipient of the transfer apparently did have to be present. ${ }^{17}$ Runs on most or all of the banks - a banking panic - which might ensue from banks promising to pay par on demand would provide further evidence of a promise to pay par. Cohen (1992, pp. 215-224) discusses one or more banking panics, although the evidence presented for panics having occurred would not be compelling against a supposition of no banking panics.

Bankers made quite risky loans. In ancient Athens, these risky loans included real estate loans, consumption loans, commercial loans and perhaps maritime loans. ${ }^{18}$ These maritime loans were loans to provide funds for items included as cargo on ships in trade. Generally, these loans were over-collateralized. If the cargo failed to generate sufficient revenue to pay off the loan, other collateral was at least sometimes available. These maritime loans are an excellent example of a loan with asymmetric information and substantial risk. The safety of passage was in doubt and the lender's risk of loss was magnified by a common provision of maritime loans: the borrower

with Cohen supporting impersonal transactions and Millett supporting personal transactions Shipton (1997) provides an excellent brief summary

${ }^{16}$ Banks were known as trapezitai, related to the root word trapeza which means "table", because of this origin as moneychangers at tables in marketplaces

17 There are some suggestions that banks provided payments at distant locations, although Millett (1991) and Cohen (1992, Chapter 5) disagree in the predictable way

18 While largely derivative of Greece, ancient Rome in the second century B C provides interesting related evidence The loans made by banks were uncollateralized loans at auctions: auctions of assets to pay debts and estate auctions (Andreau, 1999, pp 39-40) Deposits were legally distinguished between those which were to be returned intact e $g$ the actual coins deposited - which were sealed deposits and called "regular deposits" and non-sealed deposits (Andreau, 1999, pp 40-41) Some deposits paid interest; some not While it is hard to imagine that a banker paid interest on sealed deposits, for which it is more plausible that a banker charged for the safekeeping, there seems to be no clear consensus on what other deposits paid interest (Andreau, 1999, p 42) Banks made short-term loans (Andreau, 1999, p 44) There is no evidence that bankers made maritime loans out of bank assets, although the evidence does indicate that bankers were involved in receiving payments and storing contracts and as "intermediaries" (Andreau, 1999, p 56) By the second century B C, banks had at least some accounts at other banks and transfers were made from one bank to another but there is no evidence of institutions designed to facilitate such transfers (Andreau, 1999, p 58) 
owed no interest or principal if the cargo was lost enroute. ${ }^{19}$ The evidence indicates that banks financed these loans by deposits as well as the banker's own funds, in addition to soliciting funds specifically to finance maritime loans and participating in loan syndicates. ${ }^{20}$

Evidence from antiquity is informative because it is far in time from the present, but ancient practice does not seem so far removed from contemporary practice. Banks had deposits that appear to have been redeemable on demand and redemption at less than par was regarded as default. Both the liquidity and asymmetric-information explanations of why banks promise to pay par are consistent with the maritime and other loans made by banks. On other hand, this period is inconsistent with the legal restrictions theory. In addition, banks' deposits were not used as a medium of exchange; they were transferable between individuals only at the bank, and there is no evidence to suggest that the deposits were used in exchange in place of readily available coin, even in high-valued transactions.

\subsection{Italy}

After the fall of the Roman Empire about 500 A.D., banks did not exist in a recognizable form in Western Europe until the eleventh century in Southern Europe. The evidence is consistent with a supposition that the development of banks in Italy was determined more by opportunities at the time than by legal doctrines developed in the earlier Roman Empire (Lopez, 1979, pp. 1-3).

How did banking develop in Italy? Banks flourished in Italy during the Commercial Revolution from 1200 to 1500 and then went into decline with the cities of Italy. Banking in Italy in the first stage consisted of banks operated by private individuals. These banks developed from money changers, similar to development in Ancient Athens. Banks in the second stage were organized and operated as agencies of city governments. From the standpoint of understanding what profitmaximizing banks promise and why, the private banks obviously are of more interest. ${ }^{21}$

Banks in Italy had deposits that were redeemable on demand and term deposits that were not. As early as 1100 A.D., banks in Genoa accepted deposits payable on demand even though they were not required to do so and also accepted term deposits that could be redeemed only with notice, e.g. fifteen days. Florentine banks' practices are consistent with the existence of banks that paid par value on demand. In Venice, banks accepted demand and term deposits as well as deposits of valuables for which restoration of the exact articles deposited was expected. ${ }^{22}$

\footnotetext{
${ }^{19}$ Nonpayment in the case of loss of the collateral at sea is a common provision of loans on cargoes This provision can be interpreted as a defining characteristic of maritime loans (Millett, 1983, p 36), although we have not defined maritime loans this way

${ }^{20}$ See Millett (1991, pp 206-217), Cohen (1992, pp 36-40, 121-183), Shipton (1997), Andreau (1999, pp 54-56) The evidence does not rule out the possibility that term deposits financed maritime loans There is no evidence to distinguish whether or not banks used deposits payable on demand to finance maritime loans

${ }^{21}$ The first known banks in medieval times with records available are in Genoa in the twelfth century (Lopez, 1979, p 10) Banking in Italy in the 1300 s was dominated by Florentine banks Goldthwaite $(1985,1998)$ found account books for Florentine local banking - as opposed to international banking - covering the $1400 \mathrm{~s}$ and he summarizes banking in Florence a century later, including a summary of one local firm's operations Mueller $(1979,1997)$ has studied Venetian banking in detail Mueller (1997, p 8) indicates that not until almost 1300 is it possible to be sure that moneychangers in Venice had become bankers There is a clear reference to moneychangers in an 1164 contract, the names of moneychangers preserved from 1225 and the first regulation of them occurs in the 1260s (Mueller, 1997, p 8) English (1988) provides some background information in a thorough study of banking in Siena from the early 1200s to 1350 Lopez (1979, p 10) and Kindleberger (1993, pp 42-43) are additional useful references

${ }^{22}$ See Lopez (1979, pp 12-23), de Roover (1974, pp 201-202), Goldthwaite (1985, pp 19-27), Mueller (1979, p 51, 1997, pp 11-15)
} 
Because of the so-called "ghost money," an important issue in medieval Italy is the money in which banks promised to pay par. Accounts sometimes were denominated in terms of a unit of account that was not an existing coin or set of coins. ${ }^{23}$ After considering a series of examples, Spufford (1988, pp. 411-414) concludes that "it may be taken as axiomatic that on closer inspection an historical explanation may be found for the existence of each money of account, and that such an historical explanation will indicate to which real coin the system continued to be attached." In short, a money of account different than the medium of exchange provides no evidence of nonpar redemption.

Despite this promise, banks did not always pay current accounts at par value. Premia and discounts due to failure to redeem at par occurred in Venice for short periods, and their occasional appearance is not unique to Venice. ${ }^{24}$ These discounts are similar to discounts that arose during suspensions of payments in more recent periods. Despite or more likely because of these deviations from par, later centuries sometimes had explicit legal requirements that banks pay the par value of deposits on demand. Such requirements are explicit in a law in 1321. In 1421, the Venetian Senate "insisted on the total convertibility of bank money at par and on demand" (Mueller, 1979, p. 93), a clause still in force in 1477. This promise to pay par was backed up in Venice by a surety bond for bankers' deposits to provide funds to depositors in the event that a failed bank had insufficient funds. $^{25}$

The evidence for fractional reserves generally is indirect but consistent with them. Doubleentry bookkeeping was unknown for the early part of this period. A reconstructed ratio of cash to liabilities for a firm indicates that at least one Florentine bank definitely held fractional reserves. Fractional reserves also are a reasonable inference based on the later Florentine laws requiring payment on demandable deposits, for example in three days. If banks had held one hundred percent reserves, such a requirement would be superfluous, as would have been the surety bond or proposals for one hundred percent reserves. ${ }^{26}$

Bank deposits regularly were used to transfer funds between depositors. The evidence differs across cities, possibly because of real differences across times and places and possibly because of selective discussion in the histories. In Genoa, bankers transferred funds from one depositor to another by oral order and regularly transferred them from one bank to another. Funds in banks were used to make local and international payments. Written orders of payment appear in Florence in the late 1300s. Goldthwaite discusses a canonical depositor in Florence who deposited funds and then drew the balance down over several months. These withdrawals often were made by written orders to the banker to make a payment to the order's bearer. These payments could, and did, include orders to pay construction workmen, attesting to the widespread use of these deposits in payments. Transfers of deposits by oral order occurred in Venice from the end of the thirteenth century. Such transfers were used for purchasing merchandise, buying foreign exchange, lending among holders of accounts, paying real estate rents, and dealing in bullion. ${ }^{27}$

Banks made a large variety of risky loans to various people, which is consistent with banks being better informed than depositors about the banks' activities and the values of loans. Banks in

\footnotetext{
23 Cipolla (1967, Chapter IV) suggests the term "ghost monies" because the monies' names are those of monies that had not existed for some time which no one alive may have ever seen

24 Mueller (1979, pp 84-94 and 1997, pp 166-174) presents evidence on premia and discounts

25 See Mueller (1979, p 93, 1997, p 9, pp 16-17, 52-62), Lane and Mueller (1985, pp 10-16)

26 See Goldthwaite (1985, pp 37-39, Appendix B) and Mueller (1979, p 52, pp 73-74)

27 See de Roover (1974, pp 202-203, p 216), Lopez (1979, p 16), Spallanzani (1978), Goldthwaite (1985, pp 19-27), Mueller (1979, pp 48-50, 57-66, 1997, p 7, pp 15-20)
} 
Genoa made loans to relatively well-off people as well as to those engaged in trade and "craftsmen and other small fry" (Lopez, 1979, p. 17). In the eleventh century, bankers were allowed to invest in a trade but were required to obtain guarantors for their liabilities up to a specified limit. Bank loans in Genoa included maritime loans. Banks in Florence made loans based on jewelry and promissory notes and they also purchased promised interest payments from funds established by the government. Loans in Venice associated with gold and silver were extensions of short-term loans and involved failures. Venetian banks also made loans by overdrafts and became involved in government finances by buying government debt. ${ }^{28}$

The bank failures over these centuries attest to the risk that banks bore. Much of the information on banks' loans and investments comes from bankruptcies and liquidations. There were bank failures in Genoa, Florence, Venice and Siena. Florence had banking panics in the 1340s and in 1499 and 1500; Venice had one in 1374-1375. The legal aspects of failure were a topic of political discussion in Venice and inspired a bankruptcy law in 1330. In Venice, the problems generally were due to borrowers' difficulties associated with famines and war. Such events were not the only possible causes-Sienese banks made loans to ecclesiastics and nobility and failed during wars and conflicts. The problems caused for the banks were sufficiently large that debtors in Siena could seize the sons of those unable to pay. This can be contrasted with Venice's somewhat less drastic banishment and imprisonment of insolvent debtors. ${ }^{29}$

Banks in medieval Italy promised to pay par on demand, and although there were indeed laws requiring banks to pay par on demand, these laws followed rather than preceded that promise. The loans made by these banks were illiquid and the banks had better information on the risky loans made in trade and to ecclesiastics and nobility than did the depositors. Deposits were transferred across depositors and banks quite generally and, in Florence, deposits were used as a medium of exchange in the same way that checks in the United States are used today.

\subsection{Japan}

Japan developed very differently than Europe, isolated to a substantial extent from Western Europe in the Tokugawa period from 1603 to 1867-1869. A government decree in 1639 closed Japan to most foreign trade. ${ }^{30}$ Japanese were forbidden to travel to other lands, communication by private parties was cut off and foreigners were restricted to a small enclave. This period of "seclusion" ended with the arrival of Commodore Perry in 1853 to force the beginning of trade with the United States. ${ }^{31}$

Many practices easily recognizable as banking developed in Japan during this period. In fact, Japan had a developed financial system in Osaka - the major commercial center - and Edo the major administrative center later renamed Tokyo - by the late 1600s. Lenders in the country evolved into financial intermediaries that accepted deposits and made loans by the $1800 \mathrm{~s} .{ }^{32}$ While

\footnotetext{
${ }^{28}$ See Lopez (1979, p 11, 17), Goldthwaite (1985, pp 28-31), Mueller (1979, p 63, 67, pp 77-84, p 96, 1997, p 20)

${ }^{29}$ See Lopez (1979, p 20), Mueller (1997, p 57, 81, pp 122-197, 145-157, 163-164, p 197, pp 211-251, Chapter 6, Appendix B), English (1998, pp 40-41, p 49, 69, 89, Part II)

30 The Tokugawa period itself is interesting because it had some of the characteristics of a command economy well before the command economies of the twentieth century and developed characteristics of a market economy over time (Crawcour, 1989; Iwahashi, 2004)

31 See Hane (1986, pp 23-24, 65-69), Jansen (2000, Chapter 3), Tashiro (2004)

32 Prior to the Tokugawa period, lenders were not banks and instead generally lent their own funds, in most respects being similar to pawnshops (Gay, 2001)
} 
banking developed substantially after the end of the Tokugawa period, these later institutions in large part were intentional copies of those in the United States and Germany. ${ }^{33}$

Japan had a unified national coinage after the 1630s. The accounts of banks in Osaka were kept in silver and the accounts of banks in Edo were kept in gold, but a well functioning market for exchanging gold and silver developed. The major coins in actual use were gold and copper. ${ }^{34}$

By the latter half of the 1600s, firms in Osaka evolved from money changers into firms accepting deposits and issuing receipts that passed as money. These firms are known as ryogae. ${ }^{35}$ Wholesale merchants and financiers of daimyo (local lords) were involved in loans related to their original businesses. The money changers, though, were directly involved in the original issues of notes, possibly as early as 1640 to the 1660 s. These money changers, who were not corporations in the sense of English or American law, were numerous. In the 1850s, more than 1300 operated in Osaka and more than 750 operated in Edo. ${ }^{36}$

Bankers issued both bills that paid interest and passed from hand to hand, being endorsed at each step - the depositor's order - as well as notes that paid no interest and were not endorsed at each step-the ryogae's note. ${ }^{37}$ The ryogae's note was a receipt for deposits promising to pay that amount either on demand or with notice. A depositor could obtain these notes in desired denominations that passed from hand to hand. If the bank had insufficient funds upon attempted redemption, a holder's only recourse was to the bank: the ryogae's note was a liability of the bank. Deposits also were the basis of "depositor's orders" which were similar to checks except that they were negotiable. Each holder signed the depositor's order when using it to pay for something, until the note was returned to the bank. If the deposit account failed to have sufficient funds when returned to the bank, the holder's recourse was to the previous holders (possibly sequentially.) If the bank failed to honor the note because of its own difficulties rather than the depositor's lack of funds, the only recourse was to the bank. These notes could be for more than the value of the deposit, but they might not be honored on demand. ${ }^{38}$

Banks definitely held fractional reserves. While there is no clear evidence on the aggregate reserve ratio, some evidence suggests reserves on the order of one quarter of deposits. Late in the Tokugawa period, reserves of only one-sixth or one-seventh are mentioned. ${ }^{39}$ A group in Osaka known as the "Ten Money Changers" exercised supervisory control over other bankers in Osaka,

\footnotetext{
${ }^{33}$ Crawcour (1961a) provides an overview of the development of banking in Tokugawa Japan Patrick (1965, 1967) discusses the development of the banking system in the Meiji era (1868-1912) and Patrick (1967) relates it to earlier developments Soyeda (1896) and Tamaki (1995) are two general histories of Japanese banking that are primarily histories of banking after the Meiji restoration in 1868 Early chapters summarize banking in the Tokugawa period (Soyeda, 1896, Chapter 1; Tamaki, 1995, Chapter 1) Toby (2004) presents a very informative and readable account of the business activities of a country banker in the eighteenth and nineteenth centuries

${ }^{34}$ For this description of the Japanese monetary system, we have relied on Crawcour (1961a) and Crawcour and Yamamura (1970) As Crawcour notes (1961a, p 346, fn 18), the use of a money of account that is seldom used in transactions and physical monies denominated differently is not substantially different from earlier practice in Europe

35 The ryo was a counting unit of gold coin

36 See Crawcour (1961a), Tamaki (1995, Chapter 1)

37 Crawcour (1961a) calls these instruments "deposit notes" and "withdrawal notes" instead of "ryogae's notes" and "depositor's notes" as in Tamaki (1995), but the descriptions of the characteristics are the same

38 See Crawcour (1961a, pp 352-353), Soyeda (1896, pp 412-413), Tamaki (1995, pp 6-7)

39 Tamaki (1995, p 6) suggests this figure for Osaka banks and Toby (2004) suggests this figure for a country banker with surviving records Crawcour (1961a, p 356) suggests reserves for Osaka banks on the order of one-third deposits early in the Tokugawa period but possibly a ratio as low as one-sixth or one-seventh at the end of the period
} 
exercising some of the functions of a central bank. Reserves were held in other successively larger banks and used as clearing balances. ${ }^{40}$

The banks' assets were loans to private individuals, loans related to government remittances and direct loans to the local and national governments. Some banks developed from wholesalers and provided book credit, later providing credit in the form of negotiable bills. ${ }^{41}$ These loans might be secured or unsecured. There also was an active interbank market for funds. ${ }^{42}$

We have found no evidence of a legal requirement that banks redeem notes at par, and it is unlikely that there is any such requirement. The political system in the Tokugawa period included a shogun-military governor - of Japan in combination with subordinate territorial lords who ruled the country. The legal system was relatively undeveloped and civil law consisted of proclamations combined with customary law. With rare exceptions, civil disputes in the Tokugawa period were resolved by the disputants, possibly with outside but not governmental assistance. ${ }^{43}$

Overall, the development of banking in Japan is informative because banking developed in many ways similar to banking in Western Europe, despite cultural, political and legal differences from Western Europe. Banks promised to pay par on demand even though they held fractional reserves and were not required to do so. Banks made loans, such as to governments, that were not readily marketable, and loans to private individuals which would not be transparent to depositors. Banks' notes were even more clearly a medium of exchange than were Western European banks' liabilities.

\subsection{United States}

It might seem that banking in the United States is unlikely to be of much interest for this study because U.S. banking largely is a carryover of British institutions, which were developed from Italian institutions. Such a conclusion is incorrect. Institutions do not appear to have been carried over from Great Britain without innovations due to the different circumstances, although the common law and other institutions were carried over from Great Britain. In fact, some states in the antebellum period prohibited banks altogether, which clearly was not true in Great Britain, while others had novel banking systems.

\subsubsection{Free banking}

In the period immediately preceding the Civil War, individual states in the United States determined their own banking laws. Some states had a banking system patterned after the one introduced in New York, called "free banking." These free banking systems had certain distinguishing characteristics. Anyone who satisfied specific legal criteria was free to open a bank, which is the basis of the name "free banking." These banks were permitted to issue notes that were used as a medium of exchange and were required by law to redeem their notes at their par value when presented at the bank. As backing for the notes, banks were required to hold government bonds - called "government stocks" in this period - which were traded on the New York Stock Exchange. For many free banks, these bonds were the largest part of their assets. ${ }^{44}$

\footnotetext{
40 See Crawcour (1961a, pp 353-354), Soyeda (1896, p 412) and Tamaki (1995, pp 7-8)

${ }^{41}$ See Crawcour (1961a, pp 347-356, p 358; 1961b, pp 63-66; and 1989, p 586)

42 See Crawcour (1961a), Patrick (1967, p 245-247), Soyeda (1896, p 413), Tamaki (1995, pp 5-7), Toby (2004)

${ }^{43}$ Henderson (1968) and Oda (1999, Chapter 2) discuss the general framework of Tokugawa law

44 See Dwyer (1996), Dwyer and Hafer (2004), Dwyer and Hasan (2007)
} 
This requirement to redeem notes at par value is consistent with the legal requirement explanation for par redemptions. ${ }^{45}$ Since banks were required to redeem their notes at par value, an economic explanation for that redemption such as asymmetric information is not really necessary and it is not possible to be certain whether banks would have promised to pay par if they had not been required to do so. Still, it is interesting to examine whether explanations other than the legal restriction are applicable.

There is no doubt that banks held fractional reserves. While banks were required to hold virtually one hundred percent reserves of government bonds for notes, the required redemption of the notes was in gold and silver, not government bonds. Available balance sheets actually show relatively small reserves of gold and silver (Dwyer, 1996).

These bonds held as backing for the notes were marketable securities traded on the New York Stock Exchange and are not a plausible basis for an asymmetric-information explanation of banking. Banks did not obviously have better information about states' finances than did noteholders. These bonds traded on the New York Stock Exchange and prices were available in the New York press on a daily basis. Furthermore, while a bank might know more about its balance sheet than depositors, banks were required to publish their balance sheets periodically in local newspapers which mitigated any lack of information by depositors. $^{46}$

The bonds held by banks were traded on an organized exchange and were liquid in the sense that trading was reasonably continuous for the larger issues of bonds held by the banks. As a result, it is not obvious that the liquidity explanation would have been sufficient to induce par redemption.

These bonds were not risk free over time. While banking panics were not common events, there were panics and suspensions of payments in some states at the start of the Civil War (Dwyer and Hasan, 2007).

The explanation based on legal restrictions clearly applies, and banknotes issued by free banks were substantial parts of the currency in use. Because these banks held marketable assets that traded on the New York Stock Exchange, the liquidity and asymmetric-information explanations would not have been important explanations of why banks promised to pay par on demand even if they had not been required to do so.

\subsubsection{Money market funds}

Removed in time and circumstances from free banks by 150 years, money market funds in the United States are an example of firms that contradict most prevailing theories about why issuers of monetary liabilities promise to redeem deposits at par on demand. Balances in money market funds are redeemable by check on demand. Money market funds are not required by law to redeem their liabilities at anything other than market value, but money market funds have gone to substantial effort to avoid the par value of their liabilities falling below the initial value of a dollar.

The Securities and Exchange Commission's (SEC's) website describes money market funds well (SEC, 2004a).

\footnotetext{
45 Notes were not required to trade at par away from the bank, though, and they generally did not Banknote prices in New York City generally deviated by a few percentage points from the par value, although they also sometimes deviated substantially from the par value (Gorton 1996; Dwyer and Hasan, 2007)

46 See Dwyer et al (1999), Hasan and Dwyer (1994), Dwyer and Hasan (2007)
} 
Money market funds typically invest in government securities, certificates of deposits, commercial paper of companies, and other highly liquid and low-risk securities. They attempt to keep their net asset value (NAV) at a constant $\$ 1.00$ per share-only the dividend yield goes up and down. But a money market's per share NAV may fall below $\$ 1.00$ if the investments perform poorly. While investor losses in money market funds have been rare, they are possible.

Stock and bond mutual funds in the United States mark their assets to market, but money market funds do not have to use market-value accounting and do not do so. Instead money market funds use "penny rounding" and "amortized cost accounting." Under penny rounding, net asset value (NAV) is determined to the nearest one percent, rather than the nearest tenth of a percent or tenth of a penny. This technique of determining NAV avoids recognizing small losses of a few tenths of a percent. Amortized cost accounting is most easily explained in terms of securities held to maturity which have one payment at maturity. Under amortized cost accounting, the difference between the price paid and the amount received at maturity is accrued as income linearly over time. As a result, NAV cannot fall below a dollar under amortized cost accounting if all assets are held to maturity. Money market funds using these valuation techniques are required to monitor deviations of NAV from market value and their portfolios' risk and maturity are restricted. ${ }^{47}$

Both methods of valuing securities imply that the value of investors' investment is diluted when interest rates rise or fall. The underlying logic is similar to the recent controversy concerning international stock funds and applies to any fund that creates predictable deviations between NAV and market prices (Greene and Hodges, 2002). When short-term interest rates rise, the value of the assets falls and NAV does not reflect this fall. As a result, an investor in a money market fund can sell the mutual fund at NAV and buy market securities, thereby receiving the higher market interest rate which would not be received if those funds had been left in the money market fund. Because the investment was redeemed at NAV and the underlying securities were sold by the fund at the lower market prices, the remaining investors suffer a capital loss that is recognized as a lower return over time. Some investors will take advantage of this opportunity because it is worth the transactions costs to them. When interest rates are rising, money market funds have more redemptions and consequently more securities trades and higher transactions costs.

When interest rates fall, the reverse happens. Money market funds recognize capital gains on securities over time and pay higher interest rates than the subsequent return of the underlying securities. As a result, money market funds have inflows of funds and consequently more securities trades and transactions costs. The inflows of funds reduce the return received by current investors compared to what they would have been if capital gains were recognized immediately or if there were no funds inflows.

These effects were well known when these valuation techniques were adopted in the late 1970s and Lyon (1984) documented that the dilution was not merely a possibility. Lyon showed that money market funds had lower returns than the underlying portfolio when rates increased, and outflows predictably followed. Lyon's interpretation of the issue is very different than ours though. He interprets the dilution as an undesirable effect of these valuation methods which the SEC should prohibit. We interpret the dilution as a predictable cost of these valuations which customers and funds' managers are willing to pay. After all, money market funds are not required to use either valuation method, and money market funds that mark to market on a daily basis have less stringent restrictions on their portfolios.

${ }^{47}$ See Cook and Duffield (1979, pp 19-21) and SEC (2004b) 
How successful have money market funds been at keeping the redemption value constant? As of 2005, only one money market fund is known to have fallen below the dollar redemption value, Community Bankers U.S. Government Money-Market Fund which failed in 1996 and paid 94 cents on the dollar. Other money market funds have closed in circumstances that would have created an NAV less than a dollar, but the parent firm has put in funds to make up the difference. In one case, Salomon Brothers purchased securities from a subsidiary institutional money market fund at inflated prices to prevent a progressive collapse due to withdrawals (Stigum, 1983, pp. 676-679). ${ }^{48}$

This constant dollar NAV has required intermittent payments to money market funds by affiliated parties. Institutional Liquid Assets in Spring 1980 returned \$2 million in fees to keep NAV from falling below \$1. In 2002 when interest rates on assets held by money market funds fell below expense rates, money market funds reduced the expenses charged to investors in the funds to avoid having the value of the funds "bust the buck." 49

Deposits in money market funds are transferable by check. Many funds have lower limits on the size of transactions, which makes such checks generally not useful for daily transactions such as purchases at a grocery store, but the limits are sufficiently small that they can be used to make mortgage payments for example.

Money market funds clearly are not required to maintain an NAV of a dollar, which means that the legal restriction theory is irrelevant. At first glance, it might seem that money market funds must redeem at par because they compete with commercial banks, and banks in the U.S. are required to redeem demand deposits at par on demand. This leaves unanswered the question: If redemption at a constant NAV is not preferred by households, why would money market funds follow the lead of banks unless it is privately optimal to do so? It is the case that this private optimality is different in the presence of a payments system that already redeems at par-essentially the benefits of nonpar redemption would have to outweigh the costs of organizing an alternative payments system. It is not obvious that the benefits of nonpar redemption outweigh these costs. In any case, this explanation conditional on the U.S. system of required par redemption places substantial weight on the use of money market funds in payments. While it reduces the possible importance of their use as a means of payment for explaining par redemption, it still is consistent with such an explanation of money market funds' par redemption and hinges on their use in payments.

Money market funds hold marketable assets with prices that are readily available at virtually zero cost, which means that the asymmetric information theory is irrelevant. Does this mean that the liquidity provision explanation explains why money market funds keep NAV at a dollar? Because the market for Treasury bills is large relative to redemptions at money market funds to date, the assets held by money market funds can be sold at a moment's notice and are as liquid as the deposit. Whether money market funds are a medium of exchange is a matter of interpretation because there are minimum sizes of checks that can be written. Still, money market funds are checkable deposits, and with the caveat about transaction size, are consistent with this explanation. Whether the use of money market funds' deposits as a medium of exchange is the explanation of par redemption is an open question

\footnotetext{
48 Such behavior is consistent with the fund family maintaining its reputation and does not necessarily imply that there are benefits to the money market fund itself from having a stable NAV This line of argument would require that there are benefits to a fund family to a stable NAV but none to the money market fund itself This does not seem particularly plausible to us, but we do not pursue this point

49 See Lyon (1984, p 1015) and Damato (2002a)
} 
demand

reserves

on demand

from bank

\begin{tabular}{lllllll}
\hline Ancient Greece & Yes & Yes & Yes & Yes & No & No \\
Medieval Italy & Yes & Yes & Yes & Yes & No & No \\
Tokugawa Japan & Yes & Yes & Yes & Yes & Yes & Yes \\
U S Free Banking & Yes & Yes & No & No & Yes & Yes \\
U S Money Market Funds & Yes & Yes & No & No & No & No
\end{tabular}

This table summarizes the characteristics of banking in the times and places examined The theories are attempting to explain why the banks paid par on demand while holding fractional reserves; hence they are necessary for the episodes to be informative about the theories Negotiability - which means that the order to pay can be transferred to another - is a characteristic of notes that can be exchanged or of bills of exchange, but not of checks as used in the United States today "Asymmetric information" is a theoretical term based on what agents know, but is used as a summary column title to denote assets that do not have prices readily available on a reasonably continuous basis "Legal restriction" summarizes whether the institutions were required by statutory law to redeem some deposits on demand at par

${ }^{\text {a }}$ There are nontrivial restrictions on the size of transactions that limit the use of money market funds in small value transactions 


\section{Conclusion}

There is a substantial theoretical literature on banks and their promise to pay par on demand. One line of the literature follows Diamond and Dybvig, in whose model banks promise to pay par on demand because households have a demand for that contract's liquidity. In that analytical framework, the greater liquidity of the demand deposit liability is due to a maturity mismatch between the bank's assets and liabilities, but the general point is the ability to exchange the deposit for the liquid assets at low cost. A second line of the literature takes a slightly different tack and bases the promised payment at par on information about loan quality known to the bank but not to depositors. Uninformed depositors have less information about loans than do bankers, and it generally is not an incentive-compatible equilibrium for nonmarketable loans on banks' books to be the basis of deposits that are marked to a market value determined by the bank. Hence, the uncertain market value of banks' assets becomes a known value of banks' liabilities because banks promise to pay the par value of deposits. Because a bank can take actions such as making riskier loans to increase its profits without compensating depositors for the risk, promised payment on demand can reduce the bank's payoff from such strategies. An alternative line of argument takes the simple course, which is not necessarily the wrong one because it is simple. Banks in the U.S. today are required to pay the par value of "demand deposits" on demand, and the existence of such a promise may reflect nothing other than that legal requirement. A fourth line of the literature suggests that liabilities of financial intermediaries which are used as a medium of exchange will be characterized by promised redemption at par value on demand.

Each of the theories explains some observed banking arrangements. This can be seen in Table 2. Perhaps most obvious in the table is the paucity of support for the legal restriction theory, which supposes that banks pay par because they are required to do so. Other than free banks whose assets were traded on the New York Stock Exchange, the banks in these episodes have not been required to redeem their deposits on demand. Interestingly, both the liquidity explanation and the explanation based on asymmetric information fare equally well for historical banking, but neither appears to be consistent with money market funds. The theory based on deposits' use as a medium of exchange is consistent with the more recent historical episodes.

None of the theories explains all of the observed banking arrangements. Perhaps this is as it should be given the variety of arrangements that have existed in various times and places. That said, it is interesting that the most recently developed theory - the one based on money as a medium of exchange - is the one that is most consistent with recent developments.

\section{Acknowledgements}

We thank John Boyd, Ramon DeGennaro, Mardi Dungey, Robert Tamura, James Thompson, Paula Tkac and the anonymous referees for helpful comments. We benefitted from research assistance by Budina Naydenova and Lee Cohen as well as editorical assistance by Linda Mundy. Earlier versions of this paper were presented at a Society for Economic Dynamics meeting, the Tor Vergata Financial Conference, a Western Economic Association meeting and at Fordham University and the University of Carlos III. Dwyer thanks the Earhart Foundation for support of early work on this project. The views expressed here are those of the authors' and not necessarily those of the Federal Reserve Bank of Atlanta or the Federal Reserve System. Any errors are the authors' responsibility. 


\section{References}

Allen, F, Gale, D , 1998 Optimal financial crises J Finance 53 (August), 1245-1284

Alonso, I, 1996 On avoiding bank runs J Monetary Econ 37 (February), 73-87

Andreau, J , 1999 Banking and Business in the Roman World Cambridge University Press, Cambridge

Bhattacharya, S, Jorge Padilla, A, 1996 Dynamic banking: a reconsideration Rev Financial Stud 9 (Autumn), $1003-1032$

Bhattacharya, S , Fulghieri, P, Rovelli, R , 1998 Financial intermediation versus stock markets in a dynamic intertemporal model J Inst Theor Econ 154 (March), 291-319

Bryant, J 1989 Interest-bearing currency, legal restrictions, and the rate of return dominance of money J Money Credit Banking 21 (May), 240-245

Bryant, J , Wallace, N , 1984 A price discrimination analysis of monetary policy Rev Econ Stud 51 (April), 279-288

Calomiris, C W , Kahn, C M , 1991 The role of demandable debt in structuring optimal banking arrangements Am Econ Rev 81 (June), 497-513

Chari, VV, Jagannathan, R, 1988 Banking panics, information and rational expectations equilibrium J Finance 42 (July), 749-761

Cipolla, C M , 1967 Money, Prices, and Civilization in the Mediterranean World, Fifth to Seventeenth Century Gordian Press, New York

Cohen, E E, 1992 Athenian Economy and Society: A Banking Perspective Princeton University Press, Princeton

Cook, T Q, Duffield, J G , 1979 Money market mutual funds: a reaction to government regulations or a lasting financial innovation? Federal Reserve Bank of Richmond Econ Rev 65 (July/August), 15-31

Crawcour, E S , 1989 Economic change in the nineteenth century In: Jansen, M B (Ed ), The Cambridge History of Japan, Vol 5 Cambridge University Press, Cambridge, pp 569-617

Crawcour, E S ,1961a The development of a credit system in seventeenth-century Japan J Econ History 21 (September), $342-360$

Crawcour, E S , 1961b Some observations on merchants: a translation of Mitsui Takafusa's Chōnin Kōken Roku Trans Asiatic Soc Japan, Third Ser 8, 1-139

Crawcour, E S , Yamamura, K , 1970 The Tokugawa monetary system: 1787-1868 Econ Dev Cultural Change 18 (July), 489-518

Damato, K, 2002a Money funds slash their fees to stay at \$1 net asset value Wall Street Journal, October, 25

de Roover, R , 1974 New interpretations of the history of banking In: Julius Kirshner (Ed ), In Business, Banking, and Economic Thought University of Chicago Press, Chicago, pp 200-239

Diamond, D W, Rajan, R , 2006 Money in a theory of banking Am Econ Rev 96 (March), 30-53

Diamond, D W, Rajan, R , 2005 Liquidity shortages and banking crises J Finance 60 (April), 615-647

Diamond, D W, Rajan, R , 2001a Banks and liquidity Am Econ Rev 91 (May), 422-425

Diamond, D W, Rajan, R , 2001b Liquidity risk, liquidity creation and financial fragility: a theory of banking J Political Econ 109 (April), 287-327

Diamond, D W, 1997 Liquidity, banks and markets J Political Econ 105 (October), 928-956

Diamond, D W, Dybvig, PH , 1983 Bank runs, deposit insurance, and liquidity J Political Econ 91 (June), 401-419

Dwyer Jr, G P, 1996 Wildcat banking, banking panics and free banking in the United States Federal Reserve Bank of Atlanta Econ Rev 81 (December), 1-20

Dwyer Jr, G P, Hafer, R W, Weber, WE , 1999 Weekly U S and State Bond Prices 1855-1865 Historical Methods 32 (Winter), 37-42

Dwyer Jr, G P , Hafer, R W , 2004 Bank failures in banking panics: risky banks or road kill? In: Hasan, I , Hunter, W C (Eds ), Bank and Financial Market Efficiency: Global Perspectives, Vol 5, Research in Banking and Finance Elsevier Ltd, Amsterdam, pp 47-70

Dwyer, Jr, G P, Hasan, I, 2007 Suspension of payments, bank failures and the nonbank public's losses J Monetary Econ, (March), in press

Dwyer Jr, G P , Samartín Jr, M , 2006 Theoretical explanations of why banks promise to pay par on demand In: Bagella, M, Becchetti, L, Hasan, I (Eds ), Transparency, Governance and Markets Elsevier, Amsterdam, pp 1-20

Economopoulos, A , 1990 Free bank failures in New York and Wiscons: a portfolio analysis Explor Econ History (July), $421-441$

English, E D , 1988 Enterprise and Liability in Sienese Banking, 1230-1350 Medieval Academy of America, Cambridge, MA

Flannery, M , 1994 Debt maturity and the deadweight cost of leverage: optimally financing banking firms Am Econ Rev 84 (March), 320-331 
Freeman, S , 1996a The payments system, liquidity and rediscounting Am Econ Rev 86 (December), 1126-1138

Freeman, S , 1996b Clearinghouse banks and banknote over-issue J Monetary Econ 38 (August), 101-115

Friedman, M , Schwartz, A J , 1963 A Monetary History of the United States, 1867-1960 Princeton University Press, Princeton

Fulghieri, P, Rovelli, R, 1998 Capital markets, financial intermediaries and liquidity supply J Banking Finance 22 (September), 1157-1179

Gay, S , 2001 The Moneylenders of Late Medieval Kyoto University of Hawai' $i$ Press, Honolulu

Goldstein, I, Pauzner, A, 2005 Demand deposit contracts and the probability of bank runs J Finance 60 (June), $1293-1327$

Goldthwaite, R A , 1998 Banking in Florence at the end of the sixteenth century J Eur Econ History 27 (Winter), 471-536

Goldthwaite, R A, 1985 Local banking in renaissance Florence J Eur Econ History 14 (Spring), 5-55

Gorton, G, 1996 Reputation formation in early bank note markets J Political Econ 104 (April), 346-397

Gorton, G, 1988 Banking panics and business cycles Oxford Economic Papers, New Series 40 (December), 51-781

Gorton, G , Huang, L , 2002 Bank panics and the endogeneity of central banking NBER Working Paper 9102

Gorton, G, Huang, L, 2003 Banking panics and the origin of central banking In: Altig, D E, Smith, B D (Eds ),

Evolution and Procedures in Central Banking Cambridge University Press, Cambridge, pp 181-219

Gorton, G , Pennacchi, G , 1990 Financial intermediaries and liquidity creation J Finance 45 (March), 49-71

Green, E J , 1997 Money and debt in the structure of payments Bank Japan Monetary Econ Stud 15, 63-87

Green, E J , Lin, P, 2003 Implementing efficient allocations in a model of financial intermediation J Econ Theor 109 (March), 1-23

Green, E J , Lin, P, 2000 Diamond and Dybvig's classic theory of financial intermediation: What's missing? Federal Reserve Bank of Minneapolis Q Rev 24 (Winter), 3-13

Greene, J , Hodges, C W, 2002 The dilution impact of daily fund flows on open-end mutual funds J Financial Econ 65 (July), 131-158

Hane, M , 2008 Modern Japan: A Historical Survey Westview Press, Boulder, Colorado

Hasan, I , Dwyer Jr , G P , 1994 Bank runs in the free banking period J Money Credit Banking 26 (May), 271-288

Haubrich, J G, King, R G , 1990 Banking and insurance J Monetary Econ 26 (December), 361-386

Hellwig, M , 1998 Banks, markets and the allocation of risks in the economy J Inst Theor Econ 154 (March), 328-351

Hellwig, M , 1994 Liquidity provision, banking and the allocation of interest rate risk Eur Econ Rev 38 (7), 1363-1389

Henderson, D F, 1968 The evolution of Tokugawa Law In: Hall, J W, Jansen, M B (Eds ), Studies in the Institutional History of Early Modern Japan Princeton University Press, Princeton, pp 203-229

Iwahashi, M , 2004 The institutional framework of the Tokugawa economy In: Hayami, A, Saitô, O, Toby, R P (Eds ), The Economic History of Japan, Vol 1 Emergence of Economic Society in Japan, 1600-1859 Oxford University Press, Oxford, pp 85-104

Jacklin, C J , 1993 Market rate versus fixed rate demand deposits J Monetary Econ 32 (November), 237-258

Jacklin, C J , 1987 Demand deposits, trading restrictions and risk sharing In: Prescott, E C, Wallace, N (Eds ), Contractual Arrangements for Intertemporal Trade University of Minnesota Press, Minneapolis, pp 26-47

Jacklin, C J , Bhattacharya, S , 1988 Distinguishing panics and information-based bank runs: welfare and policy implications J Political Econ 96 (June), 568-592

Jansen, M B , 2000 The Making of Modern Japan The Belknap Press of Harvard University Press, Cambridge

Jean-Baptiste, E , 1999 Demand Deposits as an Incentive Mechanism Unpublished paper Wharton School, University of Pennsylvania

Kahn, C M , Roberds, W, 2004 Transferability, finality, and debt settlement Federal Reserve Bank of Atlanta Working Paper 2001, 18b

Kindleberger, C P, 1993 A Financial History of Western Europe, Second edition Oxford University Press, Oxford

Lane, F C , Mueller, R C , 1985 Coins and Monies of Account Volume I of Money and Banking in Medieval Renaissance Venice Johns Hopkins University Press, Baltimore

Lindgren, C, Garcia, G, Saal, M , 1996 Bank Soundness and Macroeconomic Policy International Monetary Fund

Lopez, R S , 1979 The dawn of medieval banking In: The Dawn of Modern Banking by The Center for Medieval and Renaissance Studies University of California at Los Angeles, Yale University Press, New Haven, Connecticut, pp $1-24$

Lyon, A B , 1984 Money market funds and shareholder dilution J Finance 39 (September), 1011-1020

McAndrews, J, Roberds, W, 1999 Payment intermediation and the origins of banking Federal Reserve Bank of Atlanta Working Paper 99-11

Millett, P, 1991 Lending and Borrowing in Ancient Athens Cambridge University Press, Cambridge 
Millett, P, 1983 Maritime loans and the structure of credit in fourth-century Athens In: Garnsey, P, Hopkins, K, Whittaker, C R (Eds ), Trade in the Ancient Economy Cambridge University Press, Cambridge, pp 36-52

Mueller, R C , 1997 The Ventetian Money Market: Banks, Panics and the Public Debt, 1200-1500 Volume II of Money and Banking in Medieval Renaissance Venice Johns Hopkins University Press, Baltimore

Mueller, R C, 1979 The role of bank money in Venice, 1300-1500 Studi Veneziani, new series 3, 47-96

Oda, H , 1999 Japanese Law, 2nd edition Oxford University Press, Oxford

Patrick, H T , 1967 Japan, 1868-1914 In: Patrick, H T, Tilly, R (Eds ), Banking in the Early Stages of Industrialization by Rondo Cameron with Olga Crisp Oxford University Press, New York, pp 239-289

Patrick, H T , 1965 External equilibrium and internal convertibility: financial policy in Meiji Japan J Econ History 25 (June), 187-213

Peck, J , Shell, K, 2003 Equilibrium bank runs J Political Econ 111 (February), 103-123

Qi, J , 1994 Bank liquidity and stability in an overlapping generations model Rev Financial Stud 7 (Summer), 389-417

Qi, J , 1998 Deposit liquidity and bank monitoring J Financial Intermediation 7 (April), 198-218

Qian, Y, John, J , John, T A , 2004 Financial system design and liquidity provision by banks and markets in a dynamic economy J Int Money Finance 23 (April), 385-402

Rolnick, A J , Weber, WE , 1984 The causes of free bank failures J Monetary Econ 14 (October), 267-291

Samartín, M , 2001 Banks increase welfare Financial Markets, Inst Instrum 10 (5), 203-234

Securities and Exchange Commission, 2004a Money Market Funds http://www sec gov/answers/mfmmkt htm visited on December 16, 2004

Securities and Exchange Commission, 2004b Rule 2a-7-Money Market Funds http://www law uc edu/CCL/InvCoRls/ rule2a-7 html visited on December 16, 2004

Shipton, K M W, 1997 The private banks in fourth-century B C Athens: a reappraisal The Classical Quarterly, New Series 47 (December), 396-422

Soyeda, J , 1896 A history of banking in japan In: Sumner, W G (Ed ), A History of Banking in all the Leading Nations, vol IV Curzon Press Ltd, Surrey, England (reprinted 1994)

Spallanzani, M, 1978 A note on Florentine banking in the renaissance: orders of payment and cheques J Eur Econ History 7 (Spring), 145-165

Sprague, O M W, 1910 History of crises under the national banking system U S National Monetary Commission, Senate Document No 538, 61 Cong , 2 Sess Government Printing Office, Washington

Spufford, P, 1988 Money and its Use in Medieval Europe Cambridge University Press, Cambridge

Stigum, M , 1983 The Money Market, Revised edition Dow Jones-Irwin, Homewood, Illinois

Tamaki, N , 1995 Japanese Banking: A History, 1859-1959 Cambridge University Press, Cambridge

Tashiro, K , 2004 Foreign trade in the Tokugawa period-particularly with Korea In: Hayami, A, Saitô, O, Toby, R P (Eds ), The Economic History of Japan Volume I, Emergence of Economic Society in Japan, 1600-1859 Oxford University Press, Oxford, pp 104-118

Temin, P, 2004 Financial intermediation in the early Roman Empire J Econ History 64 (September), 705-733

Thompson, W E, 1988 Insurance and banking In: Michael Grant, Rachel Kitzinger (Eds ), Civilization of the Ancient Mediterranean: Greece and Rome, Volume II Charles Scribner's Sons, New York, pp 829-836

Thompson, WE, 1982 The Athenian entrepreneur L'Antiquité Classique 51, 53-85

Thompson, WE, 1979 A view of Athenian banking Museum Helv 36, 224-241

Toby, R P, 2004 Country bankers in proto-industrial Japan: the transformation of credit In: Hayami, A, Saitô, O, Toby, R P (Eds ), The Economic History of Japan Volume I, Emergence of Economic Society in Japan, 1600-1859 Oxford University Press, Oxford, pp 301-336

Von Thadden, E-L, 1998 Intermediated versus direct investment: optimal liquidity provision and dynamic incentive compatibility J Financial Intermediation 7 (April), 177-197

Wallace, N , 1990 A banking model in which partial suspension is best Federal Reserve Bank Minneapolis Q Rev 14 (Fall), 11-23

Wallace, N , 1988 Another attempt to explain an illiquid banking system: the Diamond and Dybvig model with sequential service taken seriously Federal Reserve Bank of Minneapolis Q Rev 12 (Winter), 3-16

Wallace, N, 1983 A legal restrictions theory of the demand for 'money' and the role of monetary policy Federal Reserve Bank of Minneapolis Q Rev 7 (Winter), 1-7

Williamson, S D , 1992 Laissez-faire banking and circulating media of exchange J Financial Intermediation 2 (June), 134-167 